\title{
LUT
}

Lappeenranta

University of Technology

\section{The Role of Information and Communication Technologies in Paper Consumption}

Hujala Maija

This is a Final draft version of a publication

published by Inderscience

in International Journal of Business Information Systems

DOI: https://doi.org/10.1504/JJBIS.2011.038507

Copyright of the original publication: () Inderscience 2011

Please cite the publication as follows:

Hujala, M. (2011) The role of information and communication technologies in paper consumption. International Journal of Business Information Systems, Vol. 7, No. 2: 121-135. DOI: 10.1504/ IJBIS.2011.038507 
The Version of Record of this manuscript has been published and is available in International Journal of Business Information Systems, 2011, Vol. 7, No. 2: 121-135.

DOI: $\underline{\text { https://doi.org/10.1504/IJBIS.2011.038507 }}$

\title{
(C) Inderscience
}

\section{The Role of Information and Communication Technologies in Paper \\ Consumption}

\author{
Maija Hujala
}

\begin{abstract}
Conventionally paper demand is modelled by using only gross domestic product and the price of paper as explanatory variables. However, one factor affecting the demand of printing and writing papers is presumably the diffusion of information and communication technologies (ICT). In this paper, the regression analysis model and large global scale panel data sets from 1990-2007 are used to analyse the effect of ICT on paper demand for three paper grades: newsprint, office paper, and magazine paper. Results show that the internet is a substitute for newsprint, and possibly for magazine paper, and mobile telephones are complementary, and a growing number of personal computers increases office paper consumption.
\end{abstract}

\section{Introduction}

The pulp and paper industry is currently facing broad structural changes due to global shifts in demand and supply. The demand of end products, e.g. graphic papers, is growing rapidly in developing areas, namely, South-East Asia, Latin America and Eastern Europe, whereas in Western Europe and North America the growth of demand is slowing down or even decreasing. At the same time Latin America has become one of the most important pulp exporters due to eucalyptus fibre. As a consequence of these changes the focus of pulp and paper production is step by step moving to new areas, closer to the growing markets and the most cost-effective raw materials. Knowing the key factors affecting the long-term demand of paper products is important for the pulp and paper industry in the current situation. 
Traditionally paper product demand is modelled and forecasted by using gross domestic product (GDP) and the price of the product as explanatory factors (e.g. Chas-Amil and Buongiorno, 2000). However, according to Hetemäki (2005) these conventional models tend to overestimate the demand of some paper grades in the United States and some other OECD countries, since they do not take into account, for example, the possible impact of the electronic media on paper consumption: for instance, newspapers and magazines have had competition from the internet. Digital newspapers, online news services and social networking websites (like Facebook and Twitter) provide real time information and entertainment unlike traditional printed media. According to the Pew Research Center's (2006) survey, in 1998 48\% of Americans said they read a newspaper, $33 \%$ said they read a magazine and $25 \%$ said they went online yesterday. In 2006, the percentages were $40 \%, 24 \%$ and $53 \%$, respectively. The most cited reason in the survey for not to read newspapers was "too time-consuming”. According to Finnish Newspapers Association’s survey (2007), the importance of the internet among Finnish youths has grown significantly between 2001 and 2007 while at the same time the importance of newspapers has declined. It is also possible that the internet and other information and communication technologies (ICT) affect the demand of other paper grades, like office and magazine paper.

The purpose of this paper is to explore, whether different information and communication technologies have a significant role in the country-level consumption of graphic papers, and whether there are differences in the effects between paper grades. We will use the linear regression analysis model and large panel data sets to analyse the effect of ICT on the demand for three paper grades: newsprint, office paper and magazine paper. 
This paper is organised as follows. A short review of relevant studies is given in Section 2. In Section 3, we introduce our methodology and data, and develop the empirical model for paper demand. Regression analysis results are shown in Section 4, and Section 5 concludes the paper with recommendations for future research.

\section{Literature review}

Econometric studies about paper product demand have been published regularly over 30 years. One of the first published studies, Buongiorno (1977) forecasts major forest products' consumption in the developed and developing countries. A year later, Buongiorno (1978) investigated income and price elasticities in the world demand for newsprint, printing and writing papers and paperboard. Buongiorno (1978) was followed by several studies (e.g. Wibe, 1984; Baudin and Lundberg, 1987; Brooks et al., 1995; Chas-Amil and Buongiorno, 2000; Simangunsong and Buongiorno, 2001; Kangas and Baudin, 2003; Li et al., 2006) basically using the same theoretical and methodological backgrounds.

In most of the studies mentioned above, the demand models are based on the Cobb-Douglas production function and its variations. Some authors even call it the "classical model” of paper demand. Paper demand is the dependent variable, and economic activity (usually GDP) and the real price of the paper product are used as regressors.

According to Hetemäki (2008, p. 39), “at the beginning of the $21^{\text {st }}$ century, the paper industry and bulk of industry analysts still considered ICT development to enhance communication paper demand”. Thus, it is no wonder that studies about the effects of information and communication technologies on country-level paper demand are rare. Nowadays, opinions have changed, and the development of ICT is more often seen as a challenge to many paper grades, 
especially in advanced economies (Hetemäki, 2008). Still, very few econometric studies have been published in this field in recent years compared to, for example, studies concerning individuals’ choice between digital and traditional media (e.g. Flavián and Gurrea, 2006; Flavián and Gurrea, 2008; Ellonen and Kuivalainen, 2008; Klassen et al., 2009).

In one of the first studies about ICT and paper demand (Baudin and Lundberg, 1987), a number of econometric models were developed and evaluated to describe the long-term country-level demand of paper products. In one of the models, the effects of changes in other determinants of paper demand than economic activity and prices, for example the substitution of electronic media for printed media, are taken into account by adding time as an additional variable to the classical demand model. Baudin and Lundberg (1987) concluded that these time-variant factors had a positive effect on the demand for printing and writing papers and a negative effect on the newsprint between 1961 and 1981. However, data used by Baudin and Lundberg (1987) is too old to measure the effects of modern information and communication technologies on paper demand since the internet and mobile telephones did not exist before the 1980s. Time among the explanatory variables also covers all possible time variant factors affecting the country-level paper consumption, not only possible substitution of electronic media. In addition, time does not vary between countries and thus does not take into account country differences in the consumption of electronic media. Instead, for example, the internet penetration rate varies noticeably between countries (e.g., Shea et al., 2007).

Ten years later, Zhang and Buongiorno (1997) developed a model to estimate the effects of computers, televisions and radios on the demand for printed materials in the United States. Their results suggest that between 1960 and 1991, electronic media did not have a significant effect on the demand of printing and publishing papers. However, the data used by Zhang and 
Buongiorno (1997) also reflects the development before Internet age and a diffusion of mobile telephones so that their model cannot capture the effect of recent changes in people's media consumption.

The study of Zhang and Buongiorno (1997) was followed by Hetemäki and Obersteiner (2001) who computed United States newsprint demand forecasts to the year 2020 using three different models: 1) the classical model based on the Cobb-Douglas production function, 2) its Bayesian variation and 3) an ad hoc model called newspaper circulation model. In the Bayesian variation, industry experts' scenarios about economic and lifestyle development, the substitution of newspaper by electronic media and future changes in the physical measures (weight, size) of newspapers were incorporated in the estimation. The results of Hetemäki and Obersteiner (2001) indicate that the classical model cannot explain or forecast the United States newsprint demand. The future projections from the Bayesian approach also indicate only a slight decline in newsprint consumption compared to year 2000. It thus seems that the Bayesian method, i.e. incorporating qualitative data about the impact of electronic media on newsprint demand into quantitative models, is not able to forecast changes in the United States newsprint markets since the decline in the consumption has been anything but slight. According to the RISI's Industry Statistics Database the per capita consumption of newsprint has decreased from 41 kilograms to 25 kilograms between 2000 and 2007.

Bolkesjø et al. (2003) followed the method used by Hetemäki and Obersteiner (2001). They compare the classical demand model and the Bayesian approach in the newsprint demand by using panel data from Western Europe and Japan. Bolkesjø et al. (2003, p. 1651) conclude that "Bayesian models might have an advantage compared with classical models in cases of 
unprecedented structural changes, given that sufficient information other than historical data is available”.

The most recent quantitative study published in this field (Szabó et al., 2009) calculates paper and board product demand, energy consumption and emission scenarios to year 2030 using system dynamics simulation. Szabó et al. (2009) take into account the possible substitution effect of electronic media but not by using explicit measures of ICT. Instead they use behavioural parameters on the per capita income variable. Other recent studies about the ICT and paper markets (e.g. Hetemäki, 2005; Hetemäki, 2008; Hetemäki and Soirinsuo 2008) are more descriptive in nature. Hetemäki (2005; 2008) discusses the structural changes of newsprint, office paper and magazine paper markets in the United States and other OECD countries and also calculates some simple trend forecasts. According to Hetemäki (2005), there is a clear structural break in the United States newsprint market due to the impact of electronic media, and it is possible that a similar break will happen in other countries and in other paper grades.

In Hetemäki and Soirinsuo (2008), the main attention is on describing magazine paper consumption in the United States. According to them, during last four years, the magazine paper consumption has stagnated or even slightly decreased and the reason is most likely related to the increasing use of information and communication technologies. They also argue that in the future, a similar trend presumably occurs in other OECD countries, and in the long term in the developing economies.

Simon and Kadiyali (2007) have also investigated the impact of the internet on printed media although their focus is on the end product, the magazines, and not on magazine paper. They examined whether offering free digital content has an impact on the demand of printed 
magazines by using a panel data set of United States consumer magazines in 1990-2001. They conclude that digital content clearly cannibalises print sales. Thus, their results support the findings of Hetemäki and Soirinsuo (2008). On the other hand, according to Ellonen and Kuivalainen (2008, p. 393), “a successful web site may well complement rather than substitute the print magazine”. However, any global econometric studies about the impact of electronic media on magazine paper consumption have not yet been conducted.

There is clearly a gap in the existing research about the ICT and paper demand. Previous studies are either rather old, focused mainly on newsprint demand in the United States markets, and/or they measure the impact of electronic media by using qualitative data or otherwise ineffective

measures. This study contributes to the better understanding of the effect of penetration rate of ICTs on the consumption of graphic papers by using global scale data, three different types of graphic papers and explicit measures for ICT.

\section{Research methodology}

This study is limited to the bulk grades of graphic papers: newsprint, uncoated woodfree paper, uncoated mechanical paper and coated mechanical paper. Newsprint is uncoated paper mainly used in newspapers (about 80\%), telephone directories and some flyers (Diesen, 2007). Uncoated woodfree papers include, for example, copying papers, writing papers, envelopes, and offset printing papers for some books and brochures. Coated and uncoated mechanical papers are used in commercial printing (catalogues, brochures, direct mail, advertising inserts etc.) and in magazines. In this study, uncoated woodfree paper is called office paper and mechanical papers magazine paper for convenience. 
An empirical model was developed to examine the impact of information and communication technologies on the demand of newsprint, office paper and magazine paper. This model has certain similarities with the conventional paper demand model used in several previous studies (e.g. Chas-Amil and Buongiorno, 2000; Bolkesjø et al., 2003; Hetemäki and Obersteiner, 2001). However, it includes explicit measures for information and communication technologies unlike models in those studies. ICT variables are selected based on the literature and the availability of a suitable time series.

\subsection{Model specification}

\subsubsection{Classical paper demand model}

According to Bolkesjø et al. (2003), in the conventional paper demand framework, paper product is regarded as an intermediate good that together with other inputs is used to produce a final output, for example, a magazine. Assuming the production function is a Cobb-Douglas function, the cost minimization problem of the output is

$$
\min _{y, z}\left(y p_{y}+z p_{z}\right)
$$

subject to

$$
g=a y^{b} z^{c}
$$

where $y$ is the amount of paper product demanded, $p_{y}$ is the price of the paper product, $z$ is the amount of other inputs, $p_{z}$ is the price of other inputs, $g$ is the final output and $a, b$, and $c$ are positive parameters (Simangunsong and Buongiorno, 2001; Bolkesjø et al. 2003). The derived demand is then (Varian, 1984) 


$$
y=y\left(p_{y}, p_{z}, g\right)=\alpha_{0} g^{\beta_{1}}\left(\frac{p_{y}}{p_{z}}\right)^{\beta_{2}}
$$

We can define parameters $\beta_{1}=\frac{1}{(b+c)}$ and $\beta_{2}=\frac{-c}{(b+c)} \cdot \beta_{1}$ is the long-term demand elasticity of the paper product with respect to output and $\beta_{2}$ is the elasticity with respect to the real price of the paper product, compared with the price of other inputs: $p=\frac{p_{y}}{p_{z}}$ (Simangunsong and Buongiorno, 2001; Bolkesjø et al. 2003).

This theory was originally applied on the firm level, but according to Bolkesjø et al. (2003), it is commonly assumed that aggregation across firms exists, and the equation (2) can therefore be applied to country-level demand, in which case real GDP is used as the output $g$. After logarithmic transportation to achieve linearity and including an error term $\varepsilon$, the model (2) takes the form

$$
\ln y=\alpha_{0}+\beta_{1} \ln g+\beta_{2} \ln p+\varepsilon
$$

\subsubsection{Our extended model}

Our empirical model for paper demand is

$$
\ln \left(C_{i t}\right)=\alpha_{i}+\beta_{1} \ln \left(G D P_{i t}\right)+\beta_{2} \ln \left(I N T_{i t}\right)+\beta_{3} \ln \left(M O B_{i t}\right)+\beta_{4} \ln \left(P C_{i t}\right)+\beta_{5} \ln \left(T V_{i t}\right)+\varepsilon_{i t},
$$

where $i$ denotes country and $t$ is the year. The dependent variable $C_{i t}$ is the country level paper demand measured as kilograms per capita. Per capita paper demand is used in order to control 
the effect of population growth. Gross domestic product per capita $(G D P)$ as well as the penetration rates of internet users (INT), mobile telephone subscribers (MOB), personal computers $(P C)$ and televisions $(T V)$ are used as explanatory variables. The penetration rates of ICT variables are measured as cumulative numbers per 100 people, $\alpha_{i}$ are country-specific effects and $\varepsilon_{i t}$ is an idiosyncratic error. Regression coefficients $\beta_{1-} \beta_{5}$ are assumed to be common to all countries and years. Logarithmic model specification is used in order to achieve linearity.

One major difference between the classical model (3) and our model (4) is that in our model the paper price is excluded. This is mainly due to the fact that applicable price data was not available for all of the paper grades and years investigated. However, we do not consider the absence of paper price as a significant weakness in our model, since the price of final paper goods affect paper demand much more than the price of paper (Zhang and Buongiorno, 1997). According to Zhang and Buongiorno (1997), the demand for printing and publishing papers declined $4.5 \%$ annually due to the increase in the price of end products (other things equal). The increase in paper prices decreased annual paper demand only by $0.2-0.75 \%$, depending on the paper grade.

Four ICT factors mentioned above were selected as the regressors of our model for several reasons. As mentioned by Hetemäki (2005) and Hetemäki and Soirinsuo (2008), a significant reason behind the decline of newsprint and magazine paper consumption in the United States is presumably changes in people’s media behaviour. The Pew Research Center’s (2006) survey supports their assumption: getting online has become a daily routine to most of the Americans while newspapers and magazines have lost audience. Diesen (2007) also mentions new reading habits and leisure activities, online publishing, and online services providing news and 
information any time via television, computer or mobile telephone as negative drivers for newsprint and magazine paper consumption. Printed media have also lost market shares to electronic media (Diesen, 2007; Simon and Kadiyali, 2007). All of the selected four ICT variables (penetration rates of the internet, mobile telephones, computers and televisions) in our model can be regarded as a proxy of those changes in media behaviour on the country level. The more there are computers and internet users, the more time can be spent playing computer games, surfing on the internet, reading digital media and searching specific information in real time. The more there are television receivers, the more time can be spent watching news and entertainment on television. A growing number of mobile telephone subscribers gradually increases the use of mobile online services (internet access via mobile phones etc.).

Diesen (2007) and Hetemäki (2005) also list positive and negative information and communication technology related drivers of the demand for office papers: use of e-mail, electronic invoicing, and digital forms are negative drivers (less printed forms and envelopes) and growing printer, computer and copier populations are positive drivers. In this study, the number of internet users and personal computers are used to measure these negative and positive drivers. The number of mobile telephone subscribers is among the explanatory variables, for it is possible to access the internet and use e-mail via modern mobile telephones. Using the number of television receivers as an explanatory variable with office paper can be justified by the fact that some of the papers classified as uncoated woodfree papers (i.e. office papers) are used in offset printing for books and brochures. Television advertising may affect the consumption of these papers.

Hetemäki (2005) suggests an ICT index $=$ (Intenet users + mobile telephones + personal computers + televisions)/1000 people to measure the spread and use of information and 
communication technologies. However, a lot of useful information will be lost if all the four factors are simply summed together. It is possible that some of the technologies have a positive effect and some of them have a negative effect on paper consumption. These differences cannot be seen if such an ICT index is used. Therefore, in this study we choose to estimate the effects of different ICTs separately.

\subsection{Estimation methods}

The model (4) was estimated either by fixed effects or random effects estimation with statistical package Stata 10. In fixed effects estimation, explanatory variables are assumed to be independent of the error $\varepsilon_{i t}$, but the country-specific effects $\alpha_{i}$ are permitted to correlate with regressors. The consistent estimation of regression parameters requires eliminating or controlling these country-specific effects during estimation. In this study, country-specific effects were eliminated by using so-called fixed effects within estimator. In random effects estimation, $\alpha_{i}$ are assumed to be random parameters and they act as an error term together with $\varepsilon_{i t .}$ Explanatory variables are assumed to be independent of both $\alpha_{i}$ and $\varepsilon_{i t}$ for all $i$ and $t$ (e.g. Wooldridge, 2002). Random effects models were estimated using generalised least squares.

The Hausman test was used to determine which of the model specifications, the fixed or the random effects model, was more appropriate. The random effects model suffers from inconsistency if there is correlation between explanatory variables and country-specific effects. The Hausman test is used to test for orthogonality of the random effects and regressors. The fixed effects estimator is consistent under both null and alternative hypothesis of the Hausman specification test, whereas the random effects estimator is efficient under null hypothesis but inconsistent under alternative hypothesis (e.g. Wooldridge, 2002). 


\subsection{Data collection}

Three sets of country-level annual panel data for the time period 1990-2007 were used in the regression analyses: one for newsprint, one for office paper (uncoated woodfree paper) and one for magazine paper (uncoated mechanical paper + coated mechanical paper). For each country, the annual demand of different paper grades was defined by apparent consumption, namely, production plus imports minus exports. Apparent consumptions of uncoated and coated mechanical paper were summed together to achieve the demand for magazine paper.

Data on production, imports, and exports for all paper grades were obtained from the Industry Statistics Database provided by RISI. In most of the previous studies concerning the modelling of paper demand (e.g. Bolkesjø et al., 2003; Chas-Amil and Buongiorno, 2000; Simangunson and Buongiorno, 2001), data have been collected from the database provided by the Food and Agriculture Organization of the United Nations (FAO). In this study, RISI's database was used as a data source, since it provides a longer time series for some paper grades (e.g. uncoated woodfree paper) compared to FAO. Otherwise figures between these two databases are fairly similar.

In order to reduce measurement errors, countries with an apparent paper consumption of less than 10000 tons were excluded from the data. Relatively small countries that are large exporters (such as Finland, Sweden, and Norway) were excluded as well due to unreliable fluctuation in their consumption series. This volatility presumably results from the lack of information in stock changes. The country count was 50 for newsprint, 36 for magazine paper and 41 for office paper, and they were from Latin America, Europe, Asia and Africa. Both advanced economies and developing countries were included in the data sets. 
Annual paper consumption was further converted to apparent consumption per capita (measured in kilograms) by dividing by population. Populations and gross domestic products for all the selected countries in 1990-2007 were gathered from the Global Market Information Database (GMID) provided by Euromonitor International whose main data sources include national statistical offices and national and international trade associations (Euromonitor International, 2009). GDP was measured at constant US dollars at 2007 prices and fixed 2007 exchange rates, and it was converted to GDP per capita as well.

Country level cumulative numbers of internet users, mobile telephone subscribers, personal computers and televisions in 1990-2007 were obtained from the World Telecommunication/ICT Indicators 2007 Database provided by International Telecommunication Union (ITU), which is an agency of the United Nations, and the data are collected from an annual questionnaire sent out by the Telecommunication Development Bureau (BDT) of the ITU (ITU, 2009).

\section{$4 \quad$ Results and discussion}

\subsection{Descriptive statistics}

Table 1 provides descriptive statistics for the variables used in the analyses.

Table 1

As shown, the mean values of GDP per capita and ICT variables vary by paper grade, owing to the different sample of countries. The range of variation in GDP per capita is considerable (\$508-\$106,152) indicating that the data sets include both advanced economies and developing 
countries. There is a lot of variation in the values of per capita consumption of paper grades as well: from less than 1 kilogram to over 70 kilograms. Mean values are the lowest in the data on newsprint and highest in magazine paper data. This was expected, for the share of advanced economies is higher in the data on magazine paper compared to those on newsprint and office paper.

Figure 1 describes the average per capita consumption of newsprint, magazine paper and office paper in countries included in the data sets from 1990 to 2007. As shown, paper consumption seems to vary widely across years. However, this variation is, for the most part, due to missing values in data sets. On average, it seems that magazine paper consumption has increased slightly during the period and newsprint demand has stagnated since the year 2001. Also the average office paper consumption has remained approximately the same during recent years. However, one must bear in mind that there is a lot of variation between countries.

Figure 1

In turn, Figure 2 presents the average GDP per capita and the average numbers of internet users, mobile telephone subscribers, personal computers and television receivers in 50 countries included in the newsprint data. The television penetration rate is presented for the period 1990 2003 and computer penetration rate for 1990-2006 due to some missing values in some countries at the end of the time series. As shown, on average, the number of mobile telephone subscribers has increased rapidly since the mid-1990s. Internet and computer penetration rates have increased noticeably as well, but not as fast. Instead, the average number of televisions has increased only slightly during the period. Corresponding average values of the explanatory 
variables for two other data sets (magazine paper and office paper) are very similar although the mean values are slightly higher.

Figure 2

\subsection{Empirical results}

Table 2 reports the results of the estimations. Estimated coefficients are common to all the countries included in the analyses. Constant term denotes the average of country-specific values $\alpha_{i}$. The estimation method was selected based on the Hausman test. Fixed effect estimation was used for newsprint and random effects estimation for magazine paper and office paper. The results of the $F$ test (fixed effects estimation), $\chi^{2}$ test (random effects estimation) and the Hausman specification test as well as the overall coefficient of determination $\left(R^{2}\right)$ are also presented in Table 2.

Table 2

Our empirical model fits data rather well, since the overall coefficients of determination $\left(R^{2}\right.$ values) are relatively high (0.702-0.829) for all three paper grades. Thus, independent variables are able to explain $70 \%-83 \%$ of the total variation in per capita paper consumption. The $F$

(newsprint) and $\chi^{2}$ statistics (magazine paper and office paper) are tests that the coefficients of the regressors are all jointly zero. Null hypotheses are strongly rejected indicating our regression models to be significant.

Estimated coefficients of GDP per capita are positive and significant for all the paper grades. Thus, a growing gross domestic product increases the country-level consumption of these papers. This result is in line with previous studies about paper products demand (e.g. Li et al., 
2006; Kangas and Baudin, 2003; Simangunsong and Buongiorno, 2001; Hetemäki and Obersteiner, 2001).

For newsprint, the coefficient for internet penetration rate is negative and significant $(-0.043$, $\mathrm{p}<0.05)$. The effect of mobile telephone penetration rate on newsprint consumption is positive (0.074) and also significant at a 5\% level. Instead, estimated coefficients of both computer and television penetration rate are negative (-0.014 and -0.120 , respectively) but non-significant. Estimation results between newsprint and magazine paper are rather similar, but none of the estimated coefficients of ICT variables are significant for magazine paper. However, internet users (-0.036) and mobile telephone subscribers (0.050) almost have a significant effect on magazine paper consumption at a $10 \%$ significance level.

When it comes to office paper, estimated coefficients of ICT variables differ from newsprint and magazine paper. Neither the coefficient of internet penetration rate $(-0.010)$ nor mobile telephone penetration rate (0.002) is significant. Instead, personal computer penetration rate has a positive effect on office paper consumption, significant at a 5\% significance level. The estimated coefficient of diffusion of television receivers (0.052) is also positive but nonsignificant.

\subsection{Discussion}

Our empirical results appear to be logical and support the findings of previous studies (e.g. Hetemäki, 2005; Hetemäki, 2008; Hetemäki and Soirinsuo, 2008) and media surveys like that of the Pew Research Center (2006). It seems evident that changes in people's media consumption have affected newsprint consumption negatively. According to our results, the more there are internet users, the less is per capita consumption of newsprint. We presume that people read more and more often online newspapers and seek news and information from the 
internet instead of traditional newspapers. A significant negative effect of internet penetration rate along with the lack of significance for the number of computers emphasize that it is the change in media behaviour that matters, not just owning a computer. It is very likely that a similar change will happen with magazine paper in the future, since the estimated coefficients of these two paper grades were very alike (although, not statistically significant for magazine paper). In fact, according to Hetemäki and Soirinsuo (2008), the change has already started in the United States.

The insignificant effect of television penetration rate on newsprint demand is presumably due to the fact that between 1990 and 2007 the number of television receivers has increased only slightly, for example, compared to the number of internet users (see Figure 2). Either there has been no change in people’s daily routines between newspapers and television, or this variable cannot capture the change. The complementary effect of the number of mobile telephone subscribers on newsprint consumption is probably a consequence of general media intensity, and not a straightforward causal relationship. It would be naïve to claim that a growing number of mobile telephone subscribers increases newsprint consumption.

The positive effect of the number of personal computers on office paper demand may be explained by the fact that the more there are computers, the more there are printers and copying machines, and the more we will print. It thus seems that paperless offices are still far from reality. We also suppose that the lack of significance for internet penetration rate indicates that its positive and negative effects compensate each other. Although e-mail and electronic communication in general have decreased the need for writing papers and envelopes, the increase in internet usage has presumably increased printing. Many of us prefer printed copies instead of reading digital documents. 
Although our results indicate that the diffusion of information and communication technologies has significantly affected the consumption of some paper grades in the long run, the gross domestic product measured per capita is still by far the most important driver of paper demand. For example, the negative effect of internet penetration rate on newsprint consumption is very small compared to the effect of GDP per capita. According to our results, a $1 \%$ increase in the cumulative number of internet users results in a $0.04 \%$ decrease in per capita newsprint consumption, whereas a 1\% increase in GDP per capita increases newsprint consumption by 0.79\%. However, as pointed out by several studies (e.g. Hetemäki, 2005; Hetemäki, 2008; Hetemäki and Soirinsuo, 2008) there are countries in which this positive relationship between GDP and paper demand seems no longer valid. Therefore, future research is needed to further clarify the relations between ICT and paper demand.

\section{Conclusions}

This paper examined the effects of the diffusion of information and communication technologies on the consumption of newsprint, office paper and magazine paper using panel data sets from several countries between 1990 and 2007.

Information and communication technologies clearly seem to have an effect on newsprint and office paper consumption. It appears that the number of internet users has a negative impact on the per capita consumption of newsprint, and the number of mobile telephone subscribers grows hand in hand with newsprint demand. It thus seems that the internet is a substitute for newsprint. When it comes to the effects of the diffusion of ICT, office paper differs from newsprint. It appears that until now the positive drivers of the demand for office paper have exceeded the negative drivers, since the number of personal computers seems to have a positive effect on 
office paper consumption and other ICT factors are insignificant. The higher the number of computers, the higher the office paper demand. According to the results, the diffusion of information and communication technologies has not yet affected magazine paper consumption significantly, but this may change in the future.

Based on this study and the most recent previous studies, it seems evident that the ICT's effect on paper demand is something that the pulp and paper industry really needs to take into account when calculating paper demand scenarios. The substitution effect of the internet on newsprint, and possibly on magazine paper, was clearly seen in this global scale long-run research. In the future, it is very likely that this substitution effect will be much more significant than it has been so far, particularly in emerging economies, where both prosperity and the diffusion of new technologies grow rapidly.

Four ICT variables used in this paper are somewhat rough measures of the impact of electronic media on paper consumption. One suggestion for future research is to use slightly different variables to obtain more reliable results, for instance, for forecasting purposes, in which case the amount of mobile telephone traffic and data transferred could be used. Another suggestion is to group countries by economic development before the analysis, since the effect of information and communication technologies on paper consumption presumably differs between the developed and developing countries.

\section{Acknowledgements}

The Academy of Finland supported this study through the project Corporate Social Responsibility and Value Creation Challenges in the Global Forest Industry. The Author wishes to thank Professor Kaisu Puumalainen for her support and helpful comments and advice, and 
Professors Marko Torkkeli and Olli-Pekka Hilmola for their advice on publication, Minna

Vierimaa for language revision and the Anonymous Reviewers for their comments.

\section{References}

Baudin, A. and Lundberg, L. (1987) 'A World model of the demand for paper and paperboard', Forest Science, Vol. 33, No. 1, pp.185-196.

Bolkesjø, T.F., Obersteiner, M. and Solberg, B. (2003) 'Information technology and the newsprint demand in Western Europe: a Bayesian approach', Canadian Journal of Forest Research, Vol. 33, No. 9, pp.1644-1652.

Brooks, D., Baudin, A. and Schwarzbauer, P. (1995) 'Modelling forest products demand, supply and trade', UN-ECE/FAO Timber and Forest Discussion Papers ECE/TIM/DP/5, June 2009, Available at http://www.fao.org/DOCREP/003/AA036E/AA036E00.HTM

Buongiorno, J. (1977) 'Long term forecasting of major forest products consumption in developed and developing economies’, Forest Science, Vol. 23, No. 1, pp.13-25.

Buongiorno, J. (1978) 'Income and price elasticities in the world demand for paper and paperboard', Forest Science, Vol. 24, No. 2, pp.231-246.

Chas-Amil, M.L. and Buongiorno, J. (2000) 'The demand for paper and paperboard: econometric models for the European Union’, Applied Economics, Vol. 32, No. 8, pp.987999.

Diesen, M. (2007) Paper Making Science and Technology Book 1, Economics of the Pulp and Paper Industry, Jyväskylä, Finland: Paperi ja Puu Oy.

Ellonen, H.-K. and Kuivalainen, O. (2008) 'Exploring a successful magazine web site', Management Research News, Vol. 31, No. 5, pp.386-398.

Euromonitor International (2009) Research Methodology, August 2009, Available at: http://www.euromonitor.com/research_methodology.aspx

Flavián, C. and Gurrea, R. (2006) 'The role of readers' motivations in the choice of digital versus traditional newspapers', Journal of Targeting, Measurement and Analysis for Marketing, Vol. 14, No. 4, pp. 325-335.

Flavián, C. and Gurrea, R. (2008) 'Reading newspapers on the Internet: the influence of web sites’ attributes’, Internet Research, Vol. 18, No. 1, pp. 26-45.

Finnish Newspapers Association (2007) Nuorison mediankayttötutkimus (Youth Media Consumption, in Finnish), June 2009, Available at http://www.viestinet.org/liitetiedostot/SL/wwwSuomi/6/25/Nuorison_mediankayttotutk_ 2007_tiiv.pdf 
Hetemäki, L. (2005) 'ICT and Communication paper markets', in L. Hetemäki and S. Nilsson (Eds.) Information Technology and the Forest Sector, IUFRO World Series, Vol. 18, Vienna: IUFRO, pp.76-104.

Hetemäki, L. and Obersteiner, M. (2001) 'US Newsprint demand forecasts to 2020', Publications of the Fisher Center for the Strategic Use of Information Technology (FCSUIT) at the Haas School of Business, University of California, Berkeley, June 2009, Available at http://groups.haas.berkeley.edu/fcsuit/PDF-papers/LauriFisherPaper.pdf

Hetemäki, L. (2008) 'The structural change in the communication paper markets and its implications', in The Effects of a Revision of the Emission Trading Directive for the Period Starting in 2013 on th European Pulp and Paper Industry, Pellervo Economic Research Institute Reports 207, Helsinki, Finland: Pellervon taloudellinen tutkimuslaitos, pp.38-50.

Hetemäki, L. and Soirinsuo, J. (2008) 'Magazine paper consumption has started to decline in the USA', Paperi ja Puu-Paper and Timber, Vol. 90, No. 2, p.45.

ITU (2009) Information about World Telecommunication/ICT Indicators Database, July 2009, Available at http://www.itu.int/ITU-D/ict/publications/world/world.html

Kangas, K. and Baudin, A. (2003) 'Modelling forest products demand, supply and trade in Europe', Geneva Timber and Forest Discussion Papers ECE/TIM/DP/30, February 2009, Available at http://www.fao.org/DOCREP/003/AA036E/AA036E00.HTM

Klassen, M., Gupta, P. and Bunker, M.P. (2009) 'Comparison shopping on the internet', International Journal of Business Information Systems, Vol. 4, No. 5, pp.564-580.

Li, H., Luo, J. and McCarthy, P. (2006) 'Economic transition and demand pattern: Evidence from China's paper and paperboard industry’, China Economic Review, Vol. 17, No. 3, pp.321-336.

Pew Research Center (2006) Online Papers Modestly Boost Newspaper Readership: Maturing Internet News Audience-Broader than Deep, June 2009, Available at http://people-press.org/reports/display.php3?ReportID=282

Shea, T., Ariguzo, G. and White, D.S. (2007) 'Putting the world in the world wide web: the globalisation of the internet', International Journal of Business Information Systems, Vol. 2, No. 1, pp.564-580.

Simangunsong, B.C.H. and Buongiorno, J. (2001), 'International demand equations for forest products: a comparison of methods', Scandinavian Journal of Forest Research, Vol. 16, No. 2, pp.155-172.

Simon, D.H. and Kadiyali, V. (2007) 'The effect of a magazine's free digital content on its print circulation: Cannibalization or complementarity?', Information Economics and Policy, Vol. 19, No. 3-4, pp.344-361.

Szabó, L., Soria, A., Forsström, J., Keränen, J.T. and Hytönen, E. (2009) 'A world model of pulp and paper industry: Demand, energy consumption and emission scenarios to 2030', Environmental Science and Policy, Vol. 12, No. 3, pp.257-269. 
Varian, H.R. (1984) Microeconomic analysis, New York: Norton.

Wibe, S. (1984) 'Demand functions for forest products', International Institute for Applied Systems Analysis Working Paper WP-84-103, June 2009, Available at http://www.iiasa.ac.at/Admin/PUB/Documents/WP-84-103.pdf

Wooldridge, J.M. (2002) Econometric Analysis of Cross Section and Panel Data, Cambridge, Massachusetts: MIT Press.

Zhang, Y. and Buongiorno, J. (1997) 'Communication media and demand for printing and publishing papers in the United States’, Forest Science, Vol. 43, No. 3, pp.362-377.

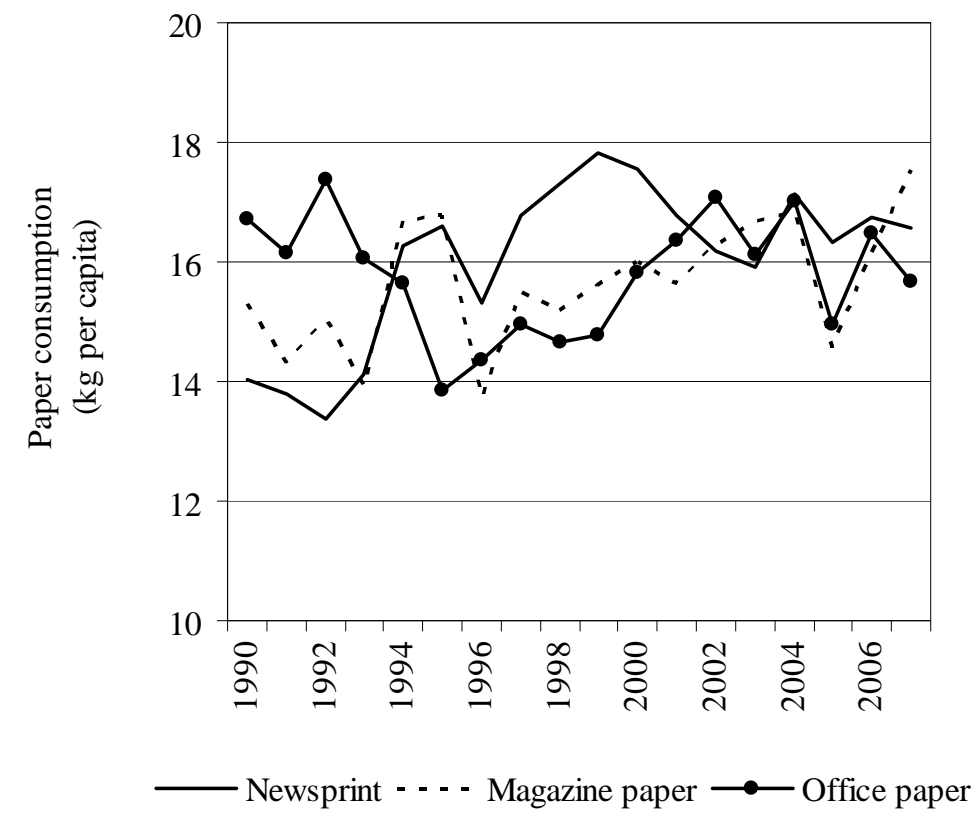

Figure 1 Average per capita consumption of newsprint, magazine paper and office paper in 1990-2007. 


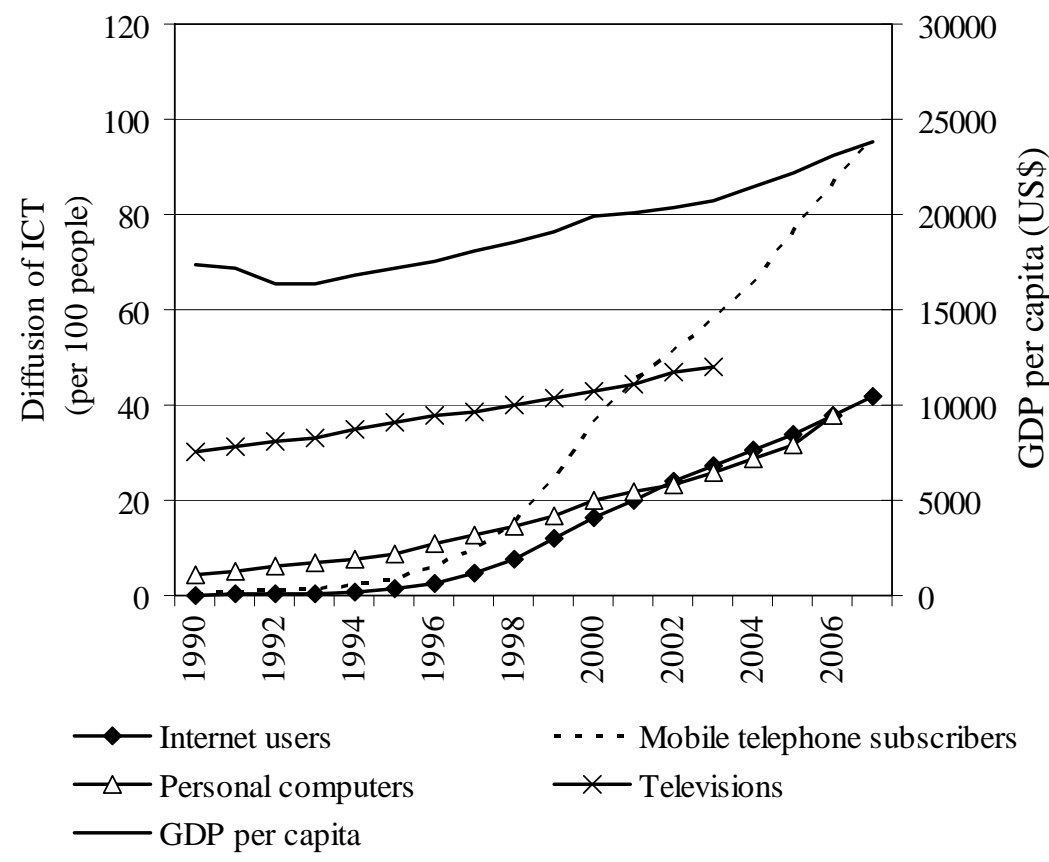

Figure 2 Average GDP per capita and penetration rates of ICT variables in 1990-2007.

Table 1 Descriptive statistics for paper consumption, GDP and ICT variables for all the countries and years with respect of paper grade.

\begin{tabular}{lcccc}
\hline & Mean & $\begin{array}{c}\text { Standard } \\
\text { deviation }\end{array}$ & Min & Max \\
\hline Newsprint (50 countries) & & & & \\
Paper consumption per capita (kg) & 16.1 & 15.0 & 0.4 & 63.3 \\
GDP per capita (US\$) & 19247 & 18145 & 508 & 106152 \\
Internet users (per 100 people) & 15.3 & 19.7 & 0.0 & 91.3 \\
Mobile telephone subscribers (per 100 people) & 31.9 & 38.0 & 0.0 & 146.4 \\
Personal computers (per 100 people) & 16.6 & 19.2 & 0.0 & 94.6 \\
Television receivers (per 100 people) & 38.6 & 19.1 & 3.2 & 110.1 \\
\hline Magazine paper (36 countries) & & & & \\
Paper consumption per capita (kg) & 16.35 & 14.27 & 0.1 & 70.9 \\
GDP per capita (US\$) & 23002 & 17278 & 508 & 83152 \\
Internet users (per 100 people) & 17.3 & 20.8 & 0.0 & 91.4 \\
Mobile telephone subscribers (per 100 people) & 35.1 & 38.9 & 0.0 & 146.4 \\
Personal computers (per 100 people) & 19.2 & 19.6 & 0.0 & 94.6 \\
Television receivers (per 100 people) & 44.0 & 19.6 & 3.2 & 155.4 \\
\hline Office paper (41 countries) & & & & \\
Paper consumption per capita (kg) & 15.6 & 11.5 & 0.5 & 57.3 \\
GDP per capita (US\$) & 19669 & 16514 & 508 & 67071 \\
Internet users (per 100 people) & 16.3 & 20.3 & 0.0 & 91.4 \\
Mobile telephone subscribers (per 100 people) & 32.7 & 38.1 & 0.0 & 146.4 \\
Personal computers (per 100 people) & 17.3 & 19.1 & 0.0 & 94.6 \\
Television receivers (per 100 people) & 40.1 & 19.7 & 2.6 & 110.1 \\
\hline
\end{tabular}


Table 2 Estimated regression coefficients for country level newsprint, magazine paper and office paper consumption.

\begin{tabular}{lccc}
\hline & $\begin{array}{c}\text { Newsprint } \\
\text { (Fixed effects } \\
\text { model) }\end{array}$ & $\begin{array}{c}\text { Magazine paper } \\
\text { (Random effects } \\
\text { model) }\end{array}$ & $\begin{array}{c}\text { Office paper } \\
\text { (Random effects } \\
\text { model) }\end{array}$ \\
\hline GDP per capita (US\$) & $0.792^{* *}$ & $1.348^{* *}$ & $0.617^{* *}$ \\
Internet users (per 100 people) & $(0.211)$ & $(0.161)$ & $(0.062)$ \\
Mobile telephone subscribers (per 100 & $-0.043^{*}$ & -0.036 & -0.010 \\
people) & $(0.021)$ & $(0.027)$ & $(0.010)$ \\
Personal computers (per 100 people) & $0.074^{*}$ & 0.050 & 0.002 \\
& $(0.029)$ & $(0.032)$ & $(0.007)$ \\
Television receivers (per 100 people) & -0.014 & -0.006 & $0.100^{*}$ \\
& $(0.071)$ & $(0.098)$ & $(0.041)$ \\
Constant term & -0.120 & -0.150 & 0.052 \\
& $(0.101)$ & $(0.174)$ & $(0.077)$ \\
\hline$F$ test & $-4.763^{*}$ & $-10.590^{* *}$ & $-3.895^{* *}$ \\
$\chi^{2}$ test & $(1.859)$ & $(0.739)$ & $(0.532)$ \\
Overall $R^{2}$ & $10.87^{* *}$ & - & - \\
Number of observations & - & $107.18^{* *}$ & $329.06^{* *}$ \\
Number of countries & 0.829 & 0.702 & 0.825 \\
Hausman specification test $\left(\chi^{2}\right.$ test) & 607 & 360 & 425 \\
\hline
\end{tabular}

Robust standard errors in parentheses

${ }^{*} \mathrm{p}<0.05,{ }^{* *} \mathrm{p}<0.01$ 